\title{
2 Practising civic professionalism through inter-professional collaboration
}

\section{Reconnecting quality with equality in the Nordic music school system}

\author{
Tuulikki Laes, Heidi Westerlund, Eva Scether, and \\ Hanna Kamensky
}

\section{Introduction}

Equality and inclusion have become paramount issues for today's public institutions, inscribed across policy frameworks and their implementation. Organisations in music education are no exception. In this chapter, we will lay the groundwork for music instrument teachers to identify their positions as civic professionals who strive towards reconnecting high-quality music school practices with the support and strengthening of the democratisation of society. We will propose the importance of inter-professional collaboration, and the potential of small social innovations as the keys to these endeavours. As the cases presented in this chapter derive from the Nordic countries, we will begin by describing the historical starting points for the democratic music education systems in Finland and Sweden.

Music education institutions develop in relation to a variety of societal issues, and many aspects of today's prevailing practices were initially conceived of as game-changers in their time and place. The Nordic "extracurricular" music schools in Finland and Sweden, initially established to complement music education in comprehensive schools, served as a manifestation of Nordic social democracy in the years following the Second World War (see Kristiansen, 1999). Indeed, music schools served the needs of modern society and Nordic democratic welfare, through offering equal opportunities for hundreds of thousands of children to receive high-quality tuition in musical instruments regardless of the geographical location of their homes or socio-economic status of their families. From that time until today, geographical and socio-economic accessibility has been seen as the most important criterion for equality. For instance, in the 1960s there were approximately 30 music schools in Finland (Kuha, 2017 , p. 588), while the current network consists of approximately 100 music schools spread across the country, serving approximately 66,000 students in total (Luoma, 2020). Since the first legislation for the Finnish music school system was established in 1969 , music schools have received state support that has

DOI: $10.4324 / 9781003108337-2$ 
enabled the rapid growth of the affordable music school network, especially in the 1980s and 1990s (Heimonen, 2002). In other words, as music schools were initiated through public funding, and continue to be supported and regulated by national policies and public means, the ideal of equality through accessibility has always been, and still is, as relevant as the ideal of high artistic quality (Björk, 2016, pp. 1-2).

In Finland, the artistic quality of the music school network has been demonstrated through the success stories of Finnish classical musicians (ibid.). However, this justification is now losing its credibility, as contemporary societal conditions differ dramatically from those of the post-war industrial economy, and the very idea of equality within educational policies has transformed altogether. In this context, educating technically skilled and talented (Western classical) musicians according to a narrow conception of artistic quality can no longer be presented as the sole justification for the existence of music schools. Consequently, the connection between equality and quality within the publicly supported system must be revised in order to respond to new values and criteria for quality, as defined by rapidly changing, plural, and diverse societies. In other words, educational systems today need to navigate between diverse - perhaps even at times incompatible - criteria for what is understood as quality in state-funded educational systems.

While initially focused on producing skilled professional classical orchestra musicians and soloists from promising young talents (e.g. Heimonen, 2002; Hofvander Trulsson et al., 2015), the Nordic music school systems today emphasise student-centred pedagogy and inclusion of new musical repertoires and musical genres. However, the original goal of high-level artistic and technical specialisation that aims towards a professional path has remained the backdrop for music schools, thus sustaining the elitist public image of the whole system (Hofvander Trulsson et al., 2015; Väkevä et al., 2017). While allegations of elitism certainly arouse emotions within the field, according to recent reports the highest participation in music schools in the capital region, both in Finland and Sweden, is among students from families of higher education levels and socio-economic status, and mostly from non-immigrant backgrounds (Kulturskoleutredningen, 2016; Vismanen et al., 2016). The recent cultural school report from Sweden (Kulturskoleutredningen, 2016) shows that there is an urgent need for redefined national objectives for the municipal music and art schools, including the need for "broad partnerships and outreach activities with the community at large" (p. 23) in order to realise wider inclusion of diverse students. Similarly, the new national core curriculum for Basic Education in the Arts in Finland emphasises matters of inclusion and accessibility more than ever before (Finnish National Agency for Education, 2017). Geographical accessibility as a primary criterion for assessing quality, when evaluating the institutional system against the various other equality demands of a welfare society, is thus no longer sufficient, and the music schools need to reconnect their practices (quality) and institutional aims (equality) with multiple criteria. Consequently, increasing migration and global mobility, followed by rapid 
changes in population structure and emerging social and political polarisation and general economic insecurity, as well as shifting understandings of inclusion and social justice in Nordic societies, position music education professionals not only as gatekeepers of artistic quality but also as key players in political democratisation processes. Along these lines, in recent music education research it has been shown that current societal changes seemingly challenge the self-serving goals and insular values of music education, including those of higher music education, which tend to focus solely on musical quality, and require individual professionals and professional networks to develop new horizons of social responsibility in a changing society (Laes et al., 2018; Westerlund et al., 2019). When considering the expectation that music schools, as well as higher education and teacher education, might act as the main catalysts for change-gamechangers - in society, this development of new horizons has become even more crucial. The question remains, however: how can more general policy level suggestions for democratising processes in Nordic countries be turned into practices within music schools and music instrument teaching?

In this chapter, we argue that the (re-)definition of the quality of music education in contemporary societies requires expanding the understanding of social responsibility, not only for teachers, but also for educational institutions and wider professional networks. Through three cases in the contexts of Nordic music school networks, namely El Sistema in Malmö, Sweden, and Floora and Resonaari in Finland, we will illustrate how music educators and music education institutions are beginning to incorporate social responsibility into their practices and engage in tackling societal problems by "going back" to the idea of civic professionalism (Tonkens, 2016), thus opening up new spaces for potential positive changes in society. As a historical and rather neglected concept, civic professionalism stems back to John Dewey's (1916) call for education professionals to be in dynamic interaction with society. It highlights the need for professionals to increase their capacity to take action alongside their fellow citizens and civic institutions to promote a more democratic society, instead of lifting themselves above "the real world" through narrow and technical overspecialisation (Boyte \& Fretz, 2010). Whilst contemporary discussion of civic professionalism mainly focuses on higher education in colleges and universities, similar issues of narrow specialisation versus social responsibility and technocratic versus participatory dynamics (Boyte \& Fretz, 2010) can be addressed in music schools (see e.g. Björk, 2016; Westerlund et al., 2019). As a whole, this chapter calls for a new coming of civic professionalism, in other words social responsibility in and through one's professional practices, within music education as imperative to the future of music school institutions, their mission and resilience, and even survival, in contemporary society. Theoretically, the three cases selected can be seen as social innovations (e.g. Mangabeira Unger, 2015; Väkevä et al., 2017) of their own time that expand the manifestation of the quality of music education. All of the case descriptions highlight the practical use of inter-professional collaboration across sectors in problem-solving, this being one possible element in realising civic professionalism in practice. 


\section{Changing the social system through inter-professional collaboration within and across institutions}

As we will argue in this chapter, encouraging teachers to strive towards civic professionalism is the key to equipping music schools with the tools to align with societal changes. Our argument is based on the idea that music schools and networks can be seen as social systems (Luhmann, 1995) that define their institutional boundaries through regulating their functions in a given social setting and distinguishing them from other institutions (Westerlund et al., 2019; Väkevä et al., 2017). Whereas modern nation-states once differentiated their institutional structures to develop and maintain the key functions of a society (e.g. educating musicians for certain occupations based on certain division of labour), in late modern societies these institutions are expected to develop resilience through reevaluating their purpose and boundaries. This means that our view of institutions as closed, autonomous, and independent systems needs to expand in order to allow for flexibility in terms of how these systems can enact changes in each other (cf. Luhmann, 1995) — without losing the quality of professional practices but vice versa, in order to maintain and transform the understanding of the quality of the institution.

In recent Finnish music education research, music school teachers have been identified as key agents in initiating change on institutional and societal levels (Laes \& Schmidt, 2016), with social innovations highlighted as one of the ways to initiate such change (Westerlund et al., 2019; Väkevä et al., 2017). According to organisational researchers, social innovations are efforts "to design initiatives in a particular part of society - an organisation, a practice, or an area of activity - that signal a promising path towards wider social change even as they meet a pressing need" (Mangabeira Unger, 2015, p. 233). They can be varying, serendipitous rather than systematic processes of designing initiatives in an organisation, a practice, or an area of activity "that seek to advance convert experiments designed to solve social problems into transformative ambition" (ibid). Such innovations can also be seen as catalytic events that provide new conditions for understanding social systems such as music schools (Väkevä et al., 2017). Supporting social innovations that create institutional resilience also requires the expansion of music education professionalism, in order to address the horizon for social responsibility in changing and complex societies. In considering music school networks as social systems that are sustained and cultivated according to their own self-defined institutional and professional boundaries, it can be argued that change from within the institution and by the professionals themselves may be more productive and feasible than changes imposed by institutional leaders, educational development policies, funders, or professionalisation strategies guided from above (Mausethagen \& Smeby, 2016; Väkevä et al., 2017). Hence, systems change and professional autonomy can be seen as mutually constitutive.

In earlier studies rethinking teachers' social responsibilities, emphasising active citizenship alone has been seen as insufficient to equip future teachers to both know what democracy means and recognise what the threats to democratisation 
are (Kennedy, 2010). Civic professionalism may therefore require more conscious use of social imagination (Greene, 1995) and sociological thinking (Bauman, 1990) in order to build stronger connections between personal experience and wider society and its structures, and to facilitate the (re-)imagining of societies. According to Maxine Greene (1995), social imagination is "the capacity to invent visions of what should be and what might be in our deficit society" (p. 5). Social imagination not only suggests but also requires that "we are moved to choose to repair or renew" (ibid). Thinking sociologically and using social imagination may help support music education professionals to understand life via relationalism, beyond issues of one's technical, musical expertise; in other words, the wider capacity to identify how people's lives are "bound up with others" (Bauman, 1990 , p. 166). Such sociological thinking is creative and transformational "as there is no final resting-place where the absolute truth resides" (p. 167). Importantly, we argue that developing a capacity for relationalism can be seen as leading to strengthening professional autonomy rather than the opposite. In other words, expanding professionalist thinking, and for example, the understanding of what musical and artistic quality is, may therefore serve as the liberator of one's professional ethos, as the teacher sees herself as part of an ever-changing society, a world of possibilities.

Furthermore, the complexity of problems in contemporary societies may require collaboration across professional groups more than ever before. Indeed, no expert group can become the "all-purpose generalist practitioner" or "complete problem-solver" (Edwards et al., 2009, p. 10). Inter-professional collaboration may be particularly necessary in institutional situations where institutional boundaries need to be crossed in order for the system as a whole to be able to respond to new demands and problems. Hence, we argue that, from the music educator's perspective, working in contexts that overlap with other professionals through mutual problem-solving, and where everyone contributes their own expertise, may open up new spaces for civic professionalism, as becomes evident in our case descriptions later in the chapter. In addition, we will show that social innovations through inter-professional collaboration may be one significant way to create resilience and increase the quality of the Nordic music school system through expanding the understanding of what is considered quality in an educational institution.

\section{Three cases of inter-professional collaboration in Nordic music school systems}

The following case descriptions bring forward three different examples of interprofessional collaboration in music school contexts in which striving towards wider accessibility, educational equality, and social change has become a driving force (see also Mangabeira Unger, 2015, p. 233). Whereas the two Finnish cases, Floora and Resonaari, are "grass-root" teacher-driven examples of gamechanging, the third example of El Sistema in Sweden shows how the need for social responsibility — as a measure of institutional quality — can be initiated from 
the policy level. Both Floora and El Sistema target an "opportunity gap" (Putnam, 2015) in an increasingly unequal society, by making an effort to reach at-risk children and adolescents who, for various reasons, appear to remain systematically outside of publicly funded music school services.

\section{Floora in Finland}

Alongside the regulated position by the Finnish National Agency for Education (2017), the public financial support received by the music schools has ensured geographical accessibility in all larger municipalities of Finland. However, recent reports have raised the issue of the rather clear ethnic, cultural, and socio-economic homogeneity of the student population within the Finnish music school system (e.g. Vismanen et al., 2016). The growing socio-economic disparities between families and living areas in Finland have made this setting even more blatant. The Floora project was initiated in 2013 by a group of individual music school instrument teachers who became conscious of their own elitist position in this societal situation.

Inter-professional collaboration across different professional and institutional sectors became the key for the initiation of Floora. Reaching the children of recently migrated families, or children whose families did not know about the possibility of studying music in government-supported music schools, required collaboration with public schools and school administrators, policymakers, and various funders, but most importantly with social workers and regional child welfare departments. Together with these collaborators, the teachers were able to create an alternative strategy for the skill-based entrance examination of the music schools in a way that meant they could reach children who had systematically been left outside the music school system. This strategy was based on the multi-professional evaluation of the needs of the children and families by professionals in schools and social and healthcare services, and its purpose was to use the existing music school network as a platform to integrate new students into the one-on-one instrumental teaching programme through bypassing the traditional entrance examination, which would have been in many cases too tense and difficult a situation for many of the Floora students. The new access strategy initiated by Floora also created tension in some of the participating music schools, as some of the school leaders did not feel comfortable with making exceptions to their own policies. This was solved by founding a separate association (www.amabilery.fi) to run the processes, consisting of two instrumental teachers, a funding expert, and an organisational expert. A significant turn took place in 2014 when the culture and leisure sector of the City of Helsinki granted funding for Floora. This collaboration created a tripartite collaboration between the city culture sector, child welfare sector, and the Amabile association, with a set of teachers who had permission from their principals to initiate the project within their music schools. With additional funding from private foundations as well as the Ministry of Education and Culture, new teachers were able to join in, and the project expanded to include several areas in Finland, simultaneously creating new 


\section{Laes et al.}

forms of professional collaboration between comprehensive schools, social and healthcare, and the third sector.

Pedagogically, music tuition in Floora does not differ from the conventional one-on-one tuition in the Finnish music schools. The one-on-one lessons were preserved as a core activity from the beginning and were seen as a more suitable practice compared to group tuition. In some early-phase child-parent group tuition situations, identifications of varying socio-economic backgrounds occurred when the parents, coming from vastly different backgrounds, met in the music school. The Floora teachers concluded that these situations may potentially jeopardise the families' right to anonymity, as their children may be recognised as "Floora students", selected for the school according to their social status. However, oneon-one tuition also had some unexpected strengths, since the children, who often came from a challenging home environment, were given dedicated, individualised time and attention by an adult. Nevertheless, Floora has not been realised without problems. Despite the positive potential, some leaders have expressed their concern over "losing the artistic quality" and "musical outcomes" when too much of the teachers' time is dedicated to students who have not been selected through entrance examinations that test their musical abilities. More than a few teachers stopped working voluntarily for Floora in the beginning of the project due to this pressure from the school's leadership, and with a feeling of failure in their attempts to combine the outspoken social values of Floora and the expectations of musical quality in educational outcomes. At the same time, with the help of inter-professional collaboration, over six years approximately 180 children have participated in music school tuition in 16 music schools in ten different municipalities, and with 70 teachers representing several different instruments and musical genres beyond Western classical music. Floora has shown that the somewhat naïve principle of "free choice" in terms of who gets to study in music schools is not enough to bridge the growing opportunity gap between the children from better-off families and those coming from less privileged backgrounds.

\section{Resonaari in Finland}

If "free choice" is one of the assumptions that prevent music schools from adapting to changing criteria of quality and equality, another is the normalisation principle, in other words the mainstreaming ideal where special students are placed in normal students' classrooms. The normalisation principle has guided general educational policy and political decision-making in Nordic countries (Kristiansen, 1999) and music schools, in which this principle still tends to maintain a distinction between those who are and those who are not able to become professional musicians within the music school system, based on their capacity to learn and perform music (Laes, 2017). Situated within the Finnish national network of music schools since early 2000s, the Resonaari Music Centre in Helsinki has pioneered what an alternative music school could look like, based on an alternative set of pedagogies and policy, and tailored towards a particular kind of student population (Laes, 2017). Many of Resonaari's students have previously 
been excluded from other music schools based on their age, ability, or physical or cognitive characteristics - or simply due to their unwillingness to study music through conventional methods and structures.

Over the last 20 years, Resonaari has become a centre of practise-based activity, and a development unit that also hosts a network for professionals working with music in cross-disciplinary fields, and organises continuing education and training for professionals in the fields of music education, therapy, social services, healthcare, and more. Resonaari has managed to create a unique shared space for inter-professional encounters between music educators, music therapists, and care professionals who want to combine elements of music and music pedagogy in their work with differently abled persons. Rather than being restricted to music therapy elements in the music education of "special needs students", Resonaari's founders and teachers (who are music educators and music therapists) have actively built a policy environment that facilitates Resonaari in breaking structural, professional, and political silos between music education and music therapy, disability services, and the educational sector. Through this, Resonaari has created its own reinterpretations of quality, underpinned particularly by criteria relating to pedagogical interaction, accessible music learning, and ethical responsibility (Laes \& Schmidt, 2016). This idea of flexible professionalism with a policy-savvy attitude can be seen to align with the definition of civic professionals who do not only follow their professional interests or maintain their professional boundaries but also "promote public goals such as social justice" (Tonkens, 2016) — in this case, to challenge the conventional and ableist understandings of who can become a musician. Indeed, the school's mission to enhance a democratic cultural revolution exemplifies the importance of disposing of professional silos and of turning to focus on building collaboration towards larger, shared goals.

In striving towards a more inclusive society as a whole, Resonaari has also developed a proactive stance on creating connections for their students between the music school and the outside world (Laes \& Schmidt, 2016) by supporting and encouraging them to become actively performing musicians and musical agents, for example in concerts where they perform with popular artists. Furthermore, Resonaari has established a training programme supporting professional musicianship for people with disabilities. This programme entails former students of Resonaari studying and working as assistant teachers within the music school, as well as performing and working as music instructors elsewhere. This programme has also led to a collaboration with higher education, as the musicians have worked as visiting teachers in a course for music teacher students at the Sibelius Academy. This collaboration has opened up new perspectives on professionalism that challenge the traditional musico-pedagogical practices in music teacher education. The encounters between Resonaari's professional musicians and future music educators at the Sibelius Academy has allowed for new diverse, nonhierarchical expert perspectives and positions, where those who are traditionally relegated to marginalised positions are taking a leading role (Laes \& Westerlund, 2018). Resonaari's case shows how music educators in particular may affect social change through embracing disability within their practices instead of relegating 


\section{Laes et al.}

it to the "special" sections of therapy or special education, thus creating more equal opportunities for students with disabilities to become visible and active agents and leaders in society as music professionals (Laes, 2017). In this respect, Resonaari's work has shown how including differently abled students within a "mainstream" system and developing alternative teaching methodologies may assist the social imagination of teachers in other music schools, helping them to reflect and consider who to teach, what to teach, and how to teach. Thus, the boundaries of music instrument teacher professionalism, as well as the definitions of musical and pedagogical quality, have been expanded.

\section{El Sistema in Sweden}

Our third case is an example of how space and location matters in music education. El Sistema in Malmö, Sweden, initiated in 2013, is an important initiative designed both to counteract increasing segregation in the city, and to pave the way for institutional changes in the municipal Arts and Music School. The Swedish El Sistema is an offspring of the original Venezuelan music education system that started in 1975, aiming to combat poverty and to offer music education for children in the streets. As such, the idea of classical music tuition as a means to "save" at-risk children, and the assumption that democracy can be promoted by giving all children the right to develop expressive tools, has not only given El Sistema many followers but has also raised critical concerns. For example, Geoffrey Baker (2014) suggests that El Sistema orchestrates youth into submission rather than liberating them, and that Western art music is not the ultimate tool for music education in a society characterised by cultural diversity. Although this critique can be answered by pointing out the need for intercultural interaction and integration, the concern needs to be kept in mind even in Malmö, where the original idea of El Sistema has been integrated into local starting points and has been used to expand and transform the established practices of the local music school. The demographic situation in Malmö, a city where 182 countries (Malmo .se, 2019) are represented, and 46\% of the 333,000 inhabitants (Malmo.se, 2019) have a foreign background (SCB, 2019), has been a challenge to the municipal Art and Music School, which according to its mission should serve all citizens (Lorensson, 2013). A closer look at the statistics shows that among those aged under 24 in Malmö, 19\% were born abroad (SCB, 2019). Since the implementation of El Sistema, the music school in Malmö has been able to include children from all backgrounds in the targeted public schools. In addition, it seems that the persistent work in socially vulnerable areas of the city has been politically convincing, as the public funding of music education is now firmly directed to the city's poor areas. As a whole, the El Sistema activities can be seen to align with the policy recommendations introduced in 2016 in the national report for the reformation of cultural schools (Kulturskoleutredningen, 2016).

At the core of Malmö El Sistema is the growing web of contacts and partnerships between the institutions involved: a new inter-professional collaboration between El Sistema music teachers, school leaders from the Arts and Music School 
and elementary schools, as well as musicians from the local symphony orchestra. Thanks to the collaboration with the Malmö Symphony Orchestra (MSO), the concert hall Malmö Live, and the selected elementary schools, the El Sistema activities facilitate the largest orchestra for children in Malmö. Furthermore, the collaboration has made it possible for the El Sistema children to attract new audiences to the municipal concert hall. The musicians in the orchestra no longer consider their work to be limited to concert halls but make regular visits to the children in their schools, demonstrating their instruments, playing, and talking about music and their musical lives. And music teachers meet the children in their elementary school environment three times a week, in this way breaking the normal music school practice in Sweden, where children are expected to travel to a music school for their weekly one-on-one instrumental lesson.

However, this inter-professional collaboration has not been painless, as teachers needed to radically rethink their own practices when trying to combine the artistic-educational objectives with the new social goals of their work. Studies with El Sistema leaders and teachers (Sæther, 2020; Sæther, 2016) reveal that challenges and sometimes difficult decisions have been a recurring theme in these discussions, and that working in culturally diverse settings has brought up unexpected situations. Equally, the leadership team of El Sistema, working within the municipal music school, had to find a balance between the need to stimulate change and how best to handle the dissonances that tend to occur when new strategies for widened participation are implemented. Consequently, inter-professional collaboration within Malmö El Sistema is evidenced in several ways that required expanding the music school's established professional practice.

Encouraging more intense contact with the parents has also been a high priority. The teachers have therefore engaged not just with intense lessons with new students but also with continuous discussions on their own work with colleagues. Inspired by shared challenges and by working together in pairs in the music classroom, the teachers have developed a new appreciation for the ethical commitment of their work and are also constantly revisiting their own value systems. For instance, whilst sometimes tiring of the public rhetoric relating to El Sistema, the teachers have avoided talking about "us" and "them", or "immigrant children", but rather created a more inclusive discourse of "children from Malmö". Moreover, the development of group teaching methods, the need for outreach concerts, and the political expectations of generating "social impact" alongside the development of musical skills, have all pushed both the teachers and the leaders out of their comfort zones. Simultaneously experimenting with the new initiative and running an established institution has meant that the strategy had to grow slowly. According to the El Sistema leaders, the key to this ethical work has been perseverance and being a regular part of the municipal Arts and Music School, instead of a temporary project. Moreover, alongside their strong commitment towards marginalised groups, the leaders have developed a sense of ownership and shared responsibilities with the staff of the music school as a whole.

Malmö El Sistema calls for civic professionalism in music education, where quality includes "a challenging and changing epistemology" (Kulturskoleutredningen, 
2016, p. 173). Co-reflection within Malmö El Sistema can be seen as strengthening the participating teachers' capacity to use their imagination in a new way in order to strengthen their sense of professional autonomy. Within this evolving language of civic professionalism, high quality is characterised by a broad range of activities, representing both contemporary artistic expression and cultural heritage, made available to all children irrespective of background or geographical residence. As stated in the policy documents, achieving this kind of high quality requires institutional boundary-crossing through structured collaboration with other institutions, and serves to strengthen the broader civic dimensions of arts education (Kulturskoleutredningen, 2016).

\section{A way forward: reconnecting quality and equality in music education systems}

In this chapter, we have argued that developing civic professionalism through inter-professional collaboration may be one way for music schools to meet the challenges of contemporary society in active and creative ways - to bridge the policy-practice gap in terms of what quality in music education systems means in the 21st century. Through wider and more conscious engagement with sociological imagination, and by working across institutional systems' borders with other professionals, music schools may widen their practical means to reconnect quality with equality. Returning to the crucial question of equality and quality requires encouraging music teachers to use their imagination to increase access to music education systems; to take the risk of breaking institutional path-dependency; to experiment with new solutions for including new groups of students; and to develop the courage to push initiatives towards novel collaborations between the different professional groups and disciplines, stakeholders, and sectors with whose cooperation tackling wider societal problems becomes more feasible.

Although inter-professional collaboration entails an overlapping of different professional practices to encourage mutual problem-solving, it does not make specialist expertise less important. Rather, collaboration beyond the bounds of one's own profession may open up greater awareness of the limits of one's own expertise, and an understanding of "when to work with others" (Edwards et al., 2009, pp. 10-11). This creates new spaces for a better understanding of the challenges and potential of shared contexts and goals, such as those developed by Floora, Resonaari, or El Sistema. In the case of Floora, collaboration with the social work sector brought new learners from diverse backgrounds to music schools and changed practices in terms of selection criteria and to whom education was made accessible. However, teachers in the Floora project have not necessarily had the need for significant pedagogical changes in their work. Collaboration between different sectors provided opportunities for teachers to be in dynamic interaction with broader society. As teachers both in Floora and Resonaari concretely realised, building a policy-savvy and influential leadership requires "co-dependency" with actors from other professional fields (Schmidt, 2020). At its best, this co-dependency and inter-professional collaboration carries the potential for creating more profound and effective systems 
change than what could otherwise be realised by one institution or professional community alone. Such systems change in turn serves each professional field, helping them to increase their social responsibility and responsiveness to societal needs, and hence creating the needed organisational resilience in established institutions.

The work and developed practices of the music teachers in the chosen cases, as well as the concomitant changes in the institutional systems, raise further questions: what kind of leadership is required for institutions to generate social innovations? How might civic professionalism be introduced to higher music education structures? Where are the places in higher music curricula to "think sociologically", so that future teachers can develop the capacity to identify how their own lives and other people's lives integrate with each other? How could social imagination, as the capacity to envision "what might be", as articulated by Maxine Greene, become part of the education of musicians and music teachers? In what ways might higher music education students develop systems thinking within music education, and take notice of when to collaborate with other professionals in their work?

Systems level thinking may indeed help with reconstructing the education of future musicians and music teachers, to reach beyond existing degrees, job markets, and aesthetic purposes in order to recognise how multiple dimensions of quality already intertwine in musical practices. In the Nordic context, equality and quality as core issues in educational politics continue to challenge music education systems, pushing forward new imaginative solutions and game-changing collaborations that can transform the limiting aspects of a narrow expertise culture in music professions towards civic professionalism.

\section{Acknowledgements}

This work was supported by the ArtsEqual project, funded by the Academy of Finland's Strategic Research Council from its Equality in Society programme under Grant [number 314223/2017].

\section{References}

Baker, G. (2014). El Sistema. Orchestrating Venezuela's Youth. Oxford University Press. Bauman, Z. (1990). Thinking Sociologically. Blackwell.

Björk, C. (2016). In Search of Good Relationships to Music: Understanding Aspiration and Challenge in Developing Music School Teacher Practices. Åbo Akademi University Press.

Boyte, H. \& Fretz, E. (2010). Civic Professionalism. Journal of Higher Education Outreach and Engagement, 14(2), 67-90.

Dewey, J. (1916). Democracy and Education. An Introduction to the Philosophy of Education. Macmillan.

Edwards, A., Daniels, H., Gallagher, T., Leadbetter, J. \& Warmington, P. (2009). Improving Inter-professional Collaborations. Routledge.

Finnish National Agency for Education. (2017). Taiteen perusopetuksen musiikin laajan oppimäärän perusteet 2017. [The core curriculum for advanced syllabus of music in the Basic Education in the Arts 2017]. Finnish National Agency for Education. 


\section{Laes et al.}

Greene, M. (1995). Releasing the Imagination: Essays on Education, the Arts, and Social Change. Jossey-Bass.

Heimonen, M. (2002). Music Education and Law. Regulation as an Instrument. Doctoral dissertation Sibelius Academy: Studia Musica 17.

Hofvander Trulsson, Y., Burnard, P. \& Söderman, J. (2015). Bourdieu and Musical Learning in a Globalized World. In P. Burnard, Y. Hofvander Trulsson \& J. Söderman (Eds.), Bourdieu and the Sociology of Music Education (pp. 209-222). Routledge.

Kennedy, K. (2010). Rethinking Teachers' Professional Responsibilities: Towards a Civic Professionalism. International Journal of Citizenship and Teacher Education, 1, 1, $3-15$.

Kristiansen, K. (1999). The Impact of Normalization and Social Role Valorization in Scandinavia. In R. J. Flynn \& R. A. Lemay (Eds.), A Quarter-century of Normalization and Social Role Valorization: Evolution and Impact (pp. 395-406). University of Ottawa Press.

Kuha, J. (2017). Suomen musiikkioppilaitoshistoriaa.Toiminta ulkomaisten esikuvien pohjalta vuoteen 1969. [History of Finland's music schools. Activities based on foreign role models until the year 1969]. Doctoral dissertation University of Helsinki: Studia musicologica Universitatis Helsingiensis, 27.

Kulturskoleutredningen. (2016). En inkluderande kulturskola på egen grund. Betänkande av Kulturskoleutredningen [An including arts and music school, on its own terms]. (SOU 2016:69). http://www.regeringen.se/rattsdokument/statens-offentliga-utredningar/2016 /10/sou-201669/

Laes, T. (2017). The Impossibility of Inclusion. Reimagining the Potential of Democratic Inclusion in and Through Activist Music Education. Doctoral dissertation Sibelius Academy: Studia Musica 72.

Laes, T. \& Schmidt, P. (2016). Activism Within Music Education. Working Towards Inclusion and Policy Change in the Finnish Music School Context. British Journal of Music Education, 33(1), 5-23.

Laes, T. \& Westerlund, H. (2018). Performing Disability in Music Teacher Education: Moving Beyond Inclusion Through Expanded Professionalism. International Journal of Music Education, 36(1), 34-46. doi:10.1177/0255761417703782.

Laes, T., Westerlund, H., Väkevä, L. \& Juntunen, M.-L. (2018). Suomalaisen musiikkioppilaitosjärjestelmän tehtävä nyky-yhteiskunnassa: Ehdotelma systeemiseksi muutokseksi. [The purpose of Finnish music school system in the current society: A suggestion for a systemic change]. Musiikki, 2, 7-27.

Lorensson, J. (2013). Opublicerat måldokument från kulturskolan i Malmö [Unpublished policy document from Kulturskolan i Malmö].

Luhmann, N. (1995). Social Systems. Stanford University Press.

Luoma, T. (2020). Taiteen perusopetus 2020. Selvitys taiteen perusopetuksenjärjestämisestä lukuvuonna 2019-2020. Raportit ja selvitykset 2020:4. Opetushallitus.

Malmo.se (2019). Official Statistics from Malmö. https://malmo.se/download/18.5661e41 0168deac741030fce/1552406690747/Malmö+i+korta+drag+181106.pdf.

Mangabeira Unger, R. (2015). Conclusion: The Task of the Social Innovation Movement. In A. Nicholls, J. Simon \& M. Gabriel (Eds.), New Frontiers in Social Innovation Research (pp. 233-251). Palgrave.

Mausethagen, S. \& Smeby, J-C. (2016). Contemporary Education Policy and Teacher Professionalism. In M. Dent, J-L Bourgeault \& D. Kuhlmann (Eds.), The Routledge Companion to the Professions and Professionalism (pp. 329-342). Routledge.

Putnam, R. (2015). Our Kids: The American Dream in Crisis. Simon \& Schuster. 
Sæther, E. (2016). Musikundervisning för Social Hållbarhet: El Sistema i Malmö. In H. Lorentz (Ed.), Interkulturella perspektiv: pedagogik i mångkulturella lärandemiljöer. Andra upplagan (pp. 209-233). Studentlitteratur.

Sæther, E. (2020). Intercultural Game in Music Teacher Education: Exploring El Sistema in Sweden. In H. Westerlund, S. Karlsen \& H. Partti (Eds.), Visions for Intercultural Music Teacher Education. Springer.

SCB (2019). Statistics from Statistiska Centralbyrån. https:/www.scb.se/hitta-statistik/ temaomraden/statistik-om-integration/statistiknyheter-om-integration/.

Schmidt, P. (2020). Policy as Practice. A Guide for Music Educators. Oxford University Press.

Tonkens, E. (2016). Professions, Service Users and Citizenship. Deliberation, Choice and Responsibility. In M. Dent, I. L. Bourgeault, J.-L. Denis \& E. Kuhlmann (Eds.), The Routledge Companion to the Professions and Professionalism (pp. 45-56). Routledge.

Väkevä, L., Westerlund, H. \& Ilmola-Sheppard, L. (2017). Social Innovations in Music Education: Creating Institutional Resilience for Increasing Social Justice. Action, Criticism, and Theory for Music Education, 16 (3), 129-147.doi:10.22176/act16.3.129

Vismanen, E., Räisänen, P. \& Sariola, R. (2016). Taiteen perusopetuksen tila ja kehittämistarpeet Helsingissä. [The state and developmental needs of the basic education of the arts in Helsinki]. Helsingin kulttuurikeskus.

Westerlund, H., Väkevä, L. \& Ilmola-Sheppard, L. 2019. How Music Schools Justify Themselves: Meeting the Social Challenges of the 21st Century. In M. Hahn and F.-O. Hofecker (Eds.), The Future of Music Schools-European Perspectives (pp. 15-33). Musikschul Management Niederästerreich GmbH. 